\title{
Assessment of Undiscovered Oil and Gas Resources of the North Caspian Basin, Middle Caspian Basin, North Ustyurt Basin, and South Caspian Basin Provinces, Caspian Sea
} Area, 2010

The U.S. Geological Survey estimated mean volumes of technically recoverable, conventional, undiscovered petroleum resources at 19.6 billion barrels of crude oil, 243 trillion cubic feet of natural gas, and 9.3 billion barrels of natural gas liquids for the Caspian Sea area, using a geologybased assessment methodology.

\section{Introduction}

The U.S. Geological Survey (USGS) estimated technically recoverable, conventional, undiscovered oil and gas resources of the Caspian Sea area as part of a program to estimate these resources for priority basins around the world. Four petroliferous geologic provinces cover the Caspian Sea area, (1) the North Caspian Basin, (2) Middle Caspian Basin, (3) North Ustyurt Basin, and (4) South Caspian Basin (fig. 1). The provinces encompass approximately 1,315,000 square kilometers and were based on interpretations by Delia and others (2008) and Natal'in and Şengör (2005). This assessment was based on published geologic information and on commercial data from oil and gas wells and fields, and field production records. The USGS approach is to define total petroleum systems and assessment units, and assess the potential for undiscovered oil and gas resources.

\section{Total Petroleum Systems and Assessment Units}

One total petroleum system (TPS), Paleozoic Composite, was defined for the North Caspian Basin Province to include source rocks ranging in age from Late Devonian through Early Permian (table 1, Ulmishek, 2001b). Five assessment units (AU) were defined geologically within this TPS. Four of the AUs lie below Lower Permian (Kungarian) evaporites (fig. 2A) - North and West Margins Subsalt AU, East and Southeast Margins Subsalt AU, South Margin Subsalt AU, and Central Basin Subsalt AU (table 1). Most reservoirs and seals in these AUs are associated with carbonate shelves and reefs, although some shelf and basin-slope clastic reservoirs of poor quality exist. Because of the extreme depths, a greater uncertainty was assumed that the Central Basin Subsalt AU contains technically recoverable oil or gas exceeding the minimum accumulation size set for the assessment ( 0.5 million barrels of oil equivalent) and therefore it was assigned a probability of 0.63 (table 1). Carbonate reefs and features associated with carbonate shelves are important traps for the subsalt AUs. Structural traps and likely stratigraphic traps are known in the East and Southeast
Margins Subsalt AU. The Suprasalt AU lies above the evaporites (fig. 2A). Reservoirs and seals in this AU include clastic rocks ranging in age from Late Permian through Cretaceous and traps are associated with salt tectonics.

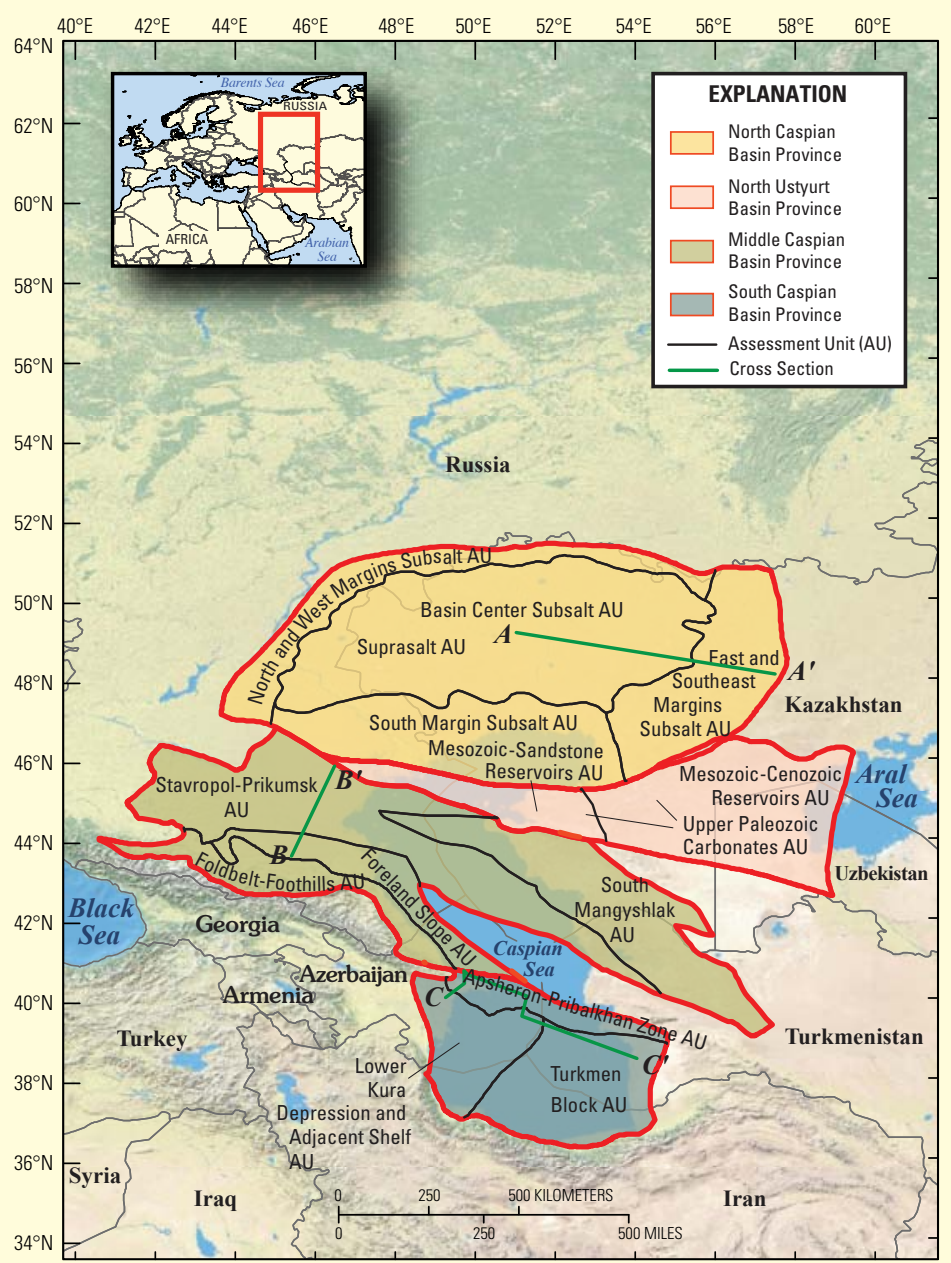

Figure 1. Location of 15 assessment units $(A U)$ in the Caspian Sea area and approximate locations of cross sections shown in figure 2. (Map not definitive for political boundaries.) 

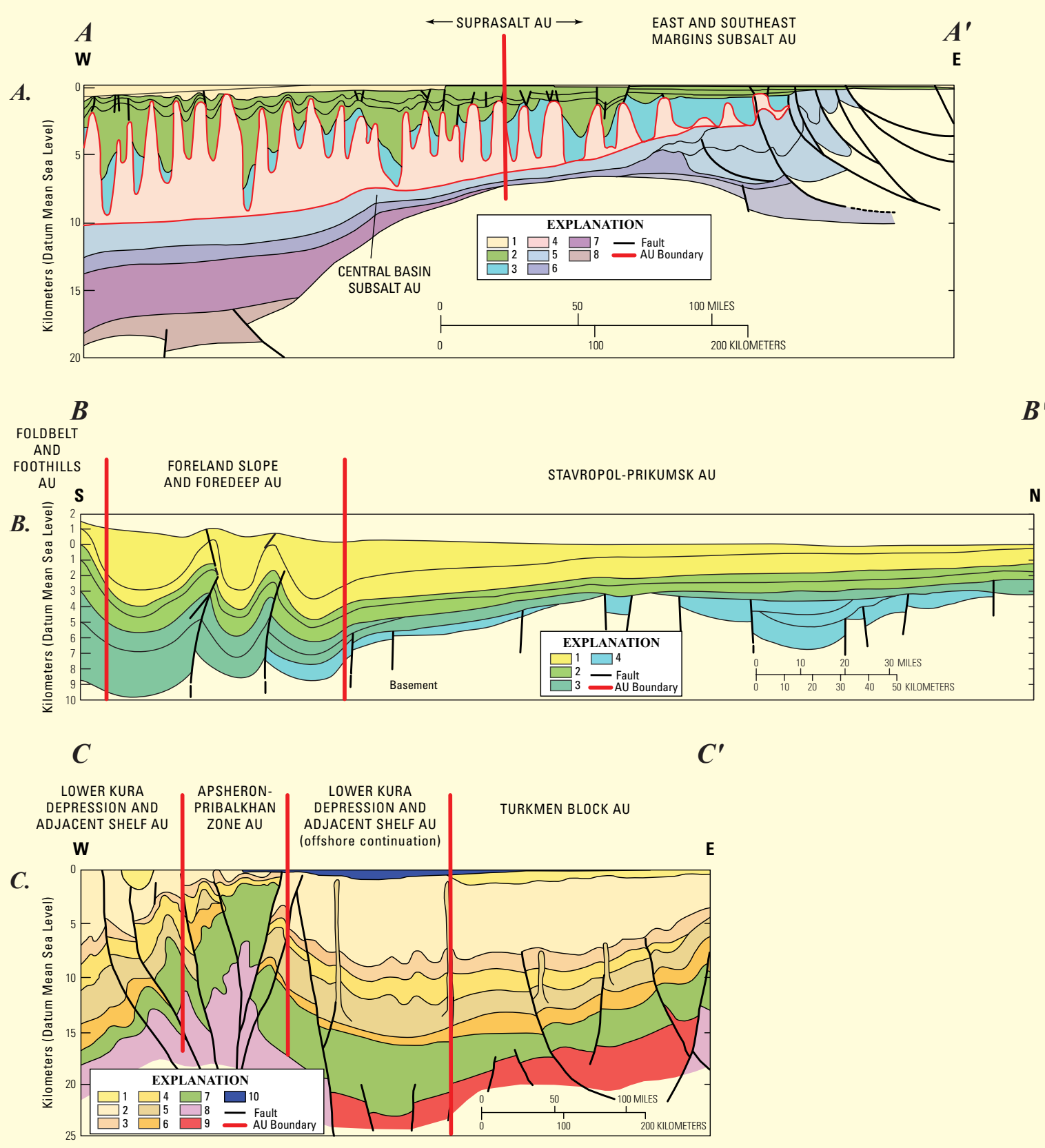

Figure 2. Schematic geologic cross sections of the Caspian Sea basins illustrating the geologic delineations of several assessment units (AU) in this study. Locations of cross sections shown in figure 1. A. North Caspian Basin Province, modified from Volozh and others (2003). Rock units: 1, Cenozoic; 2, Mesozoic; 3, Upper Permian; 4, Kungarian salt; 5, Carboniferous to Permian; 6, Devonian to Carboniferous; 7, Lower Paleozoic; 8, Proterozoic. B. Middle Caspian Basin Province, modified from Ulmishek (2001a). Rock units: 1, Cenozoic; 2, Cretaceous; 3, Jurassic; 4, Upper Permian to Triassic. C. South Caspian Basin Province, modified from Abrams and Narimanov (1997). Rock units: 1, Quaternary; 2, middle to upper Pliocene; 3, lower Pliocene; 4, Miocene; 5, Oligocene to Miocene (Maykop Formation); 6, Paleocene to Eocene; 7, Mesozoic; 8, basement, continental crust; 9, basement, oceanic crust; 10, water of the Caspian Sea.

Three TPSs were identified in the North Ustyurt Basin Province - Buzachi Arch and Surrounding Areas Composite TPS, Mesozoic-Cenozoic Composite TPS, and Paleozoic Composite TPS (table 1, Ulmishek, 2001c). The Buzachi Arch and Surrounding Areas Composite TPS was defined to include source rocks within the Buzachi Arch and possible contributions of oil and gas from the neighboring North and Middle Caspian Basins. One AU was defined for each TPS - Mesozoic Sandstone Reservoirs AU, Mesozoic-Cenozoic Reservoirs AU, and Upper Paleozoic Carbonates AU, respectively. Reservoirs and seals are indicated in the AU names. Most known traps are structural, although some pinchout traps are inferred.

The Terek-Caspian, South Mangyshlak, and StavropolPrikumsk TPSs were identified in the Middle Caspian Basin Province (table 1, Ulmishek, 2001a). Source rocks in the TerekCaspian TPS include Oligocene to Lower Miocene Maykop Formation, Eocene Kuma Formation, and possibly some Middle to Upper Jurassic subsalt mudstones. The South Mangyshlak TPS includes Triassic and possibly Jurassic source rocks. Lower Triassic, Middle Jurassic, and the Oligocene to lower Miocene 
Table 1. Caspian Sea area assessment results (technically recoverable, conventional undiscovered resources).

[MMB, million barrels; BCF, billion cubic feet. Results shown are fully risked estimates. For gas fields, all liquids are included under the natural gas liquids (NGL) category. F95 denotes a 95-percent chance of at least the amount tabulated. Other fractiles are defined similarly. Fractiles are additive under the assumption of perfect positive correlation. TPS, total petroleum system; AU, assessment unit. Gray shading indicates not applicable]

\begin{tabular}{|c|c|c|c|c|c|c|c|c|c|c|c|c|c|c|}
\hline \multirow{3}{*}{$\begin{array}{l}\text { Total Petroleum Systems } \\
\text { (TPS) } \\
\text { and Assessment Units (AU) }\end{array}$} & \multirow{3}{*}{$\begin{array}{l}\text { Field } \\
\text { type }\end{array}$} & \multirow{3}{*}{$\begin{array}{l}\text { Mean (expected) } \\
\text { largest } \\
\text { field size } \\
\text { (MMB or BCF) }\end{array}$} & \multicolumn{12}{|c|}{ Total undiscovered resources } \\
\hline & & & \multicolumn{4}{|c|}{ Oil (MMB) } & \multicolumn{4}{|c|}{ Gas (BCF) } & \multicolumn{4}{|c|}{ NGL (MMB) } \\
\hline & & & F95 & F50 & F5 & Mean & F95 & F50 & F5 & Mean & F95 & F50 & F5 & Mean \\
\hline \multicolumn{15}{|c|}{ North Caspian Basin Province, Paleozoic Composite TPS } \\
\hline \multirow{2}{*}{$\begin{array}{l}\text { North and West Margins } \\
\text { Subsalt AU }\end{array}$} & Oil & 17 & 16 & 48 & 127 & 56 & 37 & 111 & 296 & 131 & 1 & 2 & 6 & 3 \\
\hline & Gas & 199 & & & & & 250 & 736 & 1,877 & 859 & 8 & 24 & 62 & 28 \\
\hline \multirow{2}{*}{$\begin{array}{l}\text { East and Southeast Margins } \\
\text { Subsalt AU }\end{array}$} & Oil & 160 & 88 & 331 & 1,031 & 414 & 155 & 593 & 1,907 & 755 & 3 & 12 & 40 & 16 \\
\hline & Gas & 633 & & & & & 196 & 879 & 3,606 & 1,242 & 6 & 28 & 118 & 41 \\
\hline \multirow{2}{*}{ South Margin Subsalt AU } & Oil & 993 & 663 & 2,173 & 6,246 & 2,646 & 1,544 & 5,051 & 14,550 & 6,160 & 32 & 104 & 311 & 129 \\
\hline & Gas & 5,954 & & & & & 3,975 & 13,070 & 37,194 & 15,858 & 129 & 424 & 1,227 & 518 \\
\hline \multirow{2}{*}{$\begin{array}{l}\text { Central Basin Subsalt AU } \\
(\mathrm{AU} \text { probability }=0.63)\end{array}$} & Oil & & 0 & 0 & 0 & 0 & 0 & 0 & 0 & 0 & 0 & 0 & 0 & 0 \\
\hline & Gas & 3,581 & & & & & 0 & 1,515 & 14,574 & 3,592 & 0 & 49 & 475 & 117 \\
\hline \multirow{2}{*}{ Suprasalt AU } & Oil & 309 & 511 & 1,388 & 3,161 & 1,555 & 1,291 & 3,750 & 9,200 & 4,307 & 1,112 & 3,404 & 8,897 & 4,004 \\
\hline & Gas & 48 & & & & & 63 & 169 & 419 & 195 & 3 & 7 & 17 & 8 \\
\hline $\begin{array}{l}\text { Total Undiscovered Resources, } \\
\text { North Caspian Basin }\end{array}$ & & & 1,278 & 3,940 & 10,565 & 4,671 & 7,511 & 25,874 & 83,623 & 33,099 & 1,294 & 4,054 & 11,153 & 4,864 \\
\hline \multicolumn{15}{|c|}{ Middle Caspian Basin Province, Terek-Caspian TPS } \\
\hline \multirow{2}{*}{ Foldbelt-Foothills AU } & Oil & 28 & 66 & 129 & 238 & 138 & 147 & 309 & 620 & 336 & 3 & 6 & 13 & 7 \\
\hline & Gas & 154 & & & & & 300 & 616 & 1,187 & 662 & 8 & 16 & 32 & 17 \\
\hline \multirow{2}{*}{$\begin{array}{l}\text { Foreland Slope and } \\
\text { Foredeep AU }\end{array}$} & Oil & 90 & 66 & 219 & 618 & 264 & 144 & 512 & 1,586 & 642 & 3 & 11 & 33 & 13 \\
\hline & Gas & 369 & & & & & 153 & 599 & 2,133 & 795 & 4 & 16 & 57 & 21 \\
\hline \multicolumn{15}{|c|}{ Middle Caspian Basin Province, South Mangyshlak TPS } \\
\hline \multirow{2}{*}{ South Mangyshlak AU } & Oil & 116 & 145 & 374 & 855 & 422 & 324 & 879 & 2,223 & 1,023 & 21 & 57 & 152 & 68 \\
\hline & Gas & 293 & & & & & 315 & 824 & 1,972 & 940 & 13 & 35 & 86 & 40 \\
\hline \multicolumn{15}{|c|}{ Middle Caspian Basin Province, Stavropol-Prikumsk TPS } \\
\hline 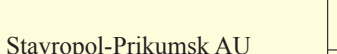 & Oil & 399 & 292 & 903 & 2,489 & 1,084 & 629 & 1,994 & 5,930 & 2,468 & 28 & 91 & 294 & 117 \\
\hline & Gas & 803 & & & & & 396 & 1,365 & 4,711 & 1,789 & 14 & 51 & 183 & 69 \\
\hline $\begin{array}{l}\text { Total Undiscovered Resources, } \\
\text { Middle Caspian Basin }\end{array}$ & & & 569 & 1,625 & 4,200 & 1,908 & 2,408 & 7,098 & 20,362 & 8,655 & 94 & 283 & 850 & 352 \\
\hline North Ustyurt Basin Province, & , Buzac & Arch and S & urroun & $\operatorname{ding} \mathbf{A r}$ & is Com & osite T & & & & & & & & \\
\hline Mesozoic Sandstone & Oil & 68 & 97 & 250 & 592 & 285 & 35 & 92 & 228 & 107 & 1 & 2 & 6 & 3 \\
\hline Reservoirs AU & Gas & 261 & & & & & 76 & 300 & 1,270 & 438 & 2 & 6 & 29 & 10 \\
\hline North Ustyurt Basin Province, & , Mesoz & zoic-Cenozoic & Compo & site TPs & & & & & & & & & & \\
\hline Mesozoic-Cenozoic & \begin{tabular}{|l|} 
Oil \\
\end{tabular} & 95 & 21 & 51 & 115 & 57 & 7 & 19 & 45 & 22 & $<1$ & 1 & 1 & 1 \\
\hline & Gas & 373 & & & & & 370 & 953 & 2,282 & 1,091 & 8 & 20 & 52 & 24 \\
\hline North Ustyurt Basin Province, & Paleoz & zoic Composite & e TPS & & & & & & & & & & & \\
\hline Upper Paleozoic & Oil & 21 & 0 & 0 & 0 & 0 & 0 & 0 & 0 & 0 & 0 & 0 & 0 & 0 \\
\hline & Gas & 425 & & & & & 851 & 2,524 & 6,762 & 2,993 & 6 & 19 & 52 & 23 \\
\hline $\begin{array}{l}\text { Total Undiscovered Resources, } \\
\text { North Ustyurt Basin }\end{array}$ & & & 118 & 301 & 707 & 342 & 1,339 & 3,888 & 10,587 & 4,651 & 17 & 48 & 140 & 61 \\
\hline South Caspian Basin Province, & e, Ceno & zoic Compos & e TPS & & & & & & & & & & & \\
\hline Apsheron-Pribalkhan & Oil & 259 & 349 & 897 & 1,997 & 1,001 & 981 & 2,608 & 6,312 & 2,997 & 12 & 32 & 80 & 38 \\
\hline & Gas & 1,149 & & & & & 319 & 1,382 & 6,226 & 2,065 & 12 & 51 & 235 & 78 \\
\hline Lower Kura Depression and & Oil & 1,731 & 634 & 2,938 & 10,744 & 3,947 & 1,743 & 8,377 & 33,632 & 11,833 & 21 & 104 & 427 & 149 \\
\hline & Gas & 10,354 & & & & & 3,859 & 17,659 & 64,260 & 23,632 & 141 & 654 & 2,469 & 889 \\
\hline Turkmen Block AU & Oil & 3,101 & 1,375 & 6,025 & 19,802 & 7,723 & 13,929 & 61,698 & 205,402 & 79,223 & 211 & 936 & 3,140 & 1,207 \\
\hline & Gas & 24,901 & & & & & 17,499 & 64,405 & 178,526 & 77,085 & 363 & 1,354 & 3,898 & 1,641 \\
\hline $\begin{array}{l}\text { Total Undiscovered Resources, } \\
\text { South Caspian Basin }\end{array}$ & & & 2,358 & 9,860 & 32,543 & 12,671 & 38,330 & 156,129 & 494,358 & 196,835 & 760 & 3,131 & 10,249 & 4,002 \\
\hline $\begin{array}{l}\text { Total Undiscovered Petroleum } \\
\text { Resources, Caspian Sea Area }\end{array}$ & & & & & & 19,592 & & & & 243,240 & & & & 9,279 \\
\hline
\end{tabular}


Maykop Formation are source rocks in the Stavropol-Prikumsk TPS. Two AUs were defined for the Terek-Caspian TPS Foldbelt-Foothills AU and Foreland Slope and Foredeep AU (fig. 2B). Reservoirs and seals in these AUs are mainly Upper Cretaceous to Eocene carbonate rocks and Lower to Upper Cretaceous and Miocene clastic rocks. One AU was defined for each of the other TPSs, having the same names as the TPS - South Mangyshlak AU and Stavropol-Prikumsk AU (fig. 2B, table 1). In the South Mangyshlak AU, reservoirs and seals exist in Lower to Middle Jurassic and Cretaceous clastic rocks, Triassic carbonates, and in fractured and weathered basement granite. Triassic carbonate rocks; Jurassic, Cretaceous, and Oligocene clastic rocks; and fractured Maykop mudstone provide reservoirs and seals in the Stavropol-Prikumsk AU. Known traps in all of the AUs are mostly structural, with some pinchout and stratigraphic traps.

The Cenozoic Composite TPS was defined for the South Caspian Basin Province (table 1) to include Oligocene to lower Miocene Maykop Formation and overlying Diatom Formation marine source rocks, and possibly also Eocene marine source rocks. The Apsheron-Pribalkhan Zone, Lower Kura Depression and Adjacent Shelf, and Turkmen Block AUs were defined in the TPS (fig. 2C). Reservoir and seal rocks are predominantly Pliocene to Pleistocene clastic rocks. Known traps include both structural and stratigraphic.

\section{Assessment Results}

Estimates of volumes of technically recoverable, conventional, undiscovered oil and gas resources are shown in table 1. No attempt was made to estimate economically recoverable resources because it is beyond the scope of this study. The combined mean undiscovered petroleum resources in the Caspian Sea area are 19.6 billion barrels of recoverable crude oil, 243 trillion cubic feet of recoverable natural gas, and 9.3 billion barrels of recoverable natural gas liquids.

In the North Caspian Basin Province, the mean volumes and probability ranges $\left(\mathrm{F}_{95}\right.$ to $\left.\mathrm{F}_{05}\right)$ of undiscovered petroleum are approximately 4,671 million barrels (MMB) of crude oil, with a range of 1,278 to $10,565 \mathrm{MMB} ; 33,099 \mathrm{BCF}$ of natural gas (both associated and dissolved, and nonassociated), with a range of 7,511 to 83,623 billion cubic feet (BCF); and 4,864 MMB of natural gas liquids, with a range of 1,294 to 11,153 MMB.

In the North Ustyurt Basin Province, the mean volumes and probability ranges $\left(\mathrm{F}_{95}\right.$ to $\left.\mathrm{F}_{05}\right)$ of undiscovered oil are approximately $342 \mathrm{MMB}$ of crude oil, with a range of 118 to $707 \mathrm{MMB} ; 4,651 \mathrm{BCF}$ of natural gas (both associated and dissolved, and nonassociated), with a range of 1,339 to 10,587 $\mathrm{BCF}$; and $61 \mathrm{MMB}$ of natural gas liquids, with a range of 17 to $140 \mathrm{MMB}$.

In the Middle Caspian Basin Province, the mean volumes and probability ranges $\left(\mathrm{F}_{95}\right.$ to $\left.\mathrm{F}_{05}\right)$ of undiscovered oil are approximately $1,908 \mathrm{MMB}$ of crude oil, with a range of 569 to 4,200 MMB; 8,655 BCF of natural gas (both associated and dissolved, and nonassociated), with a range of 2,408 to 20,362 $\mathrm{BCF}$; and $352 \mathrm{MMB}$ of natural gas liquids, with a range of 94 to $850 \mathrm{MMB}$.
In the South Caspian Basin Province, the mean volumes and probability ranges $\left(\mathrm{F}_{95}\right.$ to $\left.\mathrm{F}_{05}\right)$ of undiscovered oil are approximately $12,671 \mathrm{MMB}$ of crude oil, with a range of 2,358 to $32,543 \mathrm{MMB} ; 196,835 \mathrm{BCF}$ of natural gas (both associated and dissolved, and nonassociated), with a range of 38,330 to 494,358 BCF; and 4,002 MMB of natural gas liquids, with a range of 760 to $10,249 \mathrm{MMB}$.

\section{References Cited}

Abrams, M.A., and Narimanov, A.A., 1997, Geochemical evaluation of hydrocarbons and their potential sources in the western South Caspian depression, Republic of Azerbaijan: Marine and Petroleum Geology, v. 14, no. 4, p. 451-468.

Delia, S.V., Kerusov, I.N., Kosova, S.S., and Shilkin, S., 2008, Principal stages and specific features of geotectonics in the northern part of the Middle Caspian [abs]: European Association of Geoscientists and Engineers Conference Petroleum Geology and Hydrocarbon Potential of Caspian and Black Sea Regions, 6-8 October 2008, Baku, Azerbaijan, A17.

Natal'in, B.A., and Şengör, A.M.C., 2005, Late Paleozoic to Triassic evolution of the Turan and Scythian platforms: The pre-history of the Palaeo-Tethyan closure: Tectonophysics, v. 404 , p. $175-202$.

Ulmishek, G.F., 2001a, Petroleum geology and resources of the Middle Caspian Basin, Former Soviet Union: U.S. Geological Survey Bulletin 2201-A, 38 p.

Ulmishek, G.F., 2001b, Petroleum geology and resources of the North Caspian Basin, Kazakhstan and Russia: U.S. Geological Survey Bulletin 2201-B, 25 p.

Ulmishek, G.F., 2001c, Petroleum geology and resources of the North Ustyurt Basin, Kazakhstan and Uzbekistan: U.S. Geological Survey Bulletin 2201-D, 14 p.

Volozh, Yu.A., Antipov, M.P., Brunet, M.-F., Garagash, I.A., Lobkovshii, L.I., and Cadet, J.-P., 2003, Pre-Mesozoic geodynamics of the Precaspian Basin (Kazakhstan): Sedimentary Geology, v. 156, p. 35-58.

\section{For Further Information}

Publications detailing the geology and the methodology for the Caspian Sea area and assessment results are available at the USGS Energy Program Web site, http://energy.cr.usgs.gov/ oilgas/.

\section{Caspian Sea Area Assessment Team}

T.R. Klett (tklett@usgs.gov), Christopher J. Schenk, Ronald R. Charpentier, Donald L. Gautier, Michael E. Brownfield, Janet K. Pitman, Troy A. Cook, and Marilyn E. Tennyson.

\section{Acknowledgments}

Geographic Information Systems support by Christopher P. Anderson, ATA Services. Graphic support by Wayne Husband, ATA Services. 